\title{
Human Scalp Hair (HSH) Waste as an Alternative for Reducing Invasive Activity of Wild Hog: A Preliminary Study
}

\author{
Nur Suraya Kamsano ${ }^{1 *}$, Johan Sohaili ${ }^{2}$, Shantha Kumari Muniyandi ${ }^{3}$, Nur Sumaiyyah Supian ${ }^{1}$ \\ ${ }^{1}$ Department of Environmental Engineering, School of Civil Engineering, Faculty of Engineering, Universiti \\ Teknologi Malaysia, 81310 Johor Bahru, Johor, Malaysia \\ 2, Institute of Environmental and Water Resource Management, Universiti Teknologi Malaysia, 81310 Johor \\ Bahru, Johor, Malaysia \\ ${ }^{3}$ Department of Quantity Surveying, Faculty of Built Environment, Tunku Abdul Rahman Universiti College, \\ Jalan Genting Kelang, 53300 Kuala Lumpur, Wilayah Persekutuan Kuala Lumpur, Malaysia
}

*Corresponding author: nursuraya@utm.my

\begin{abstract}
Article History
Received: May 7, 2018 Received in revised form: November 10, 2018 Accepted: November 21, 2018 Published Online: February 10, 2019
\end{abstract}

\begin{abstract}
The weaknesses in the human hair waste management system has brought many environmental problems that are rarely taken into account. In most of rural areas, this waste is still being used by farmers to protect their plantation from wild hog attacks. However, this traditional practice is seem unpopular and has little exposure. Study in the past related to this waste in Malaysia is still far behind compared to other countries. Moreover, the past practices of this waste as repellent did not highlight the prior procedure and their effectiveness as pest controller to control invasive activity of wild hog. This study aims to briefly discuss on the conflict of human and wild hog, past mitigation practices, potential usage of hair waste as temporary repellent and to share the result of 5 days pilot study through field trial conducted in small orchard in Muar. In this study, fermented corn bait has been applied at the study area to increase the activities and probability of visitation of wild hog. Four (4) samples were placed in the private orchard namely (A) $5 \mathrm{~kg}$ whole kernel corn; (B) $5 \mathrm{~kg}$ whole kernel corn mixed with $20 \mathrm{~g}$ of hair; (C) $5 \mathrm{~kg}$ whole kernel corn mixed with $40 \mathrm{~g}$ hair; and (D) $5 \mathrm{~kg}$ whole kernel corn mixed with $60 \mathrm{~g}$ hair. The result during feeding test is observed and analysed. Through this pilot study, it indicates the potential of hair waste application as a temporary wild hog repellent.
\end{abstract}

Keywords: Hair waste; pest controller; waste management; value proposition, temporary repellent

\subsection{INTRODUCTION}

Wild hog is an exotic and invasive mammals that always causes the problem in agricultural sector. Previous study showed that the most significant effect contributed by invasion of this economic pests can be seen on agricultural crop [1, 2, 3]. In a study conducted by Bratton [4], the rooting activities during the invasion has not only affect the structure of the plantation, but at the same time has altered the composition of plantation species. Furthermore, this invasive species has also contribute to the extinction of rare plant species and assisting in dieback disease (Phytophthora cinnamon), which is death of woody plantation through symptoms such as death of roots, shoots and twigs [5]. Despite of so many negative opinions related to this pest, their existence also play an undeniable role especially in biodiversity for plantation species as seed dispersal vertebrate [6]. Past study in Sweden by Welander [7] has shown that the existence of wild hog has enriches the soil and plantation species. However, over the years, the need for this species overlaps with human needs which ultimately leads to several negative impacts primarily to crop losses and quality [8]. The problem of invasive activities of this species in agricultural land is exacerbated by their ability to adapt to new environment and restore their population [9]. This has eventually led to a phenomenon of human-wildlife conflicts (HWC). The worst case reported was in the early 70's in Changkat Cermin, Perak 
where more than 15 acres of young tapioca plantation were damaged by 25 wild pigs [10].

Several methods of mitigation such as hunting, using fences and food supplementary has been implemented to reduce the invasive activities of wild hog. However, in term of economic aspect, they are not cost-effective. As the use of hair waste has become one of traditional alternative as temporary repellent to overcome the problem of wild hog invasion, this study is conducted to share the result of probability application of hair waste as temporary repellent and to promote the value proposition of hair waste as cost-effective temporary repellent in reducing the invasive activities and human-wildlife conflict for wild hog. This study is expected to be beneficial for agricultural industry, farmers and agricultural business practitioner. This study also give platform for a better and optional waste management for hair salon operator and possible future policies related to its management and operation.

\subsection{Human-Widlife Conflict (HWC) on Agricultural land}

Study conducted in Australia has shown impact due to invasion of this animal. The damage reported caused by the attack of this species has caused losses of at least $\$ 100 \mathrm{M}$ per year [11]. IUCN's Invasive Species Specialist Group has also listed this species in the top 100 "World worst invasive animal" [12]. This issue that has been contributed by conflict which known as human-wildlife conflict (HWC) mainly targeting on the agriculture area. Basically the HWC cases depend on the species of wildlife that living in the area that also shared by human. In a study made by [13], the conflict of HWC existed throughout the history as human and wildlife sharing same habitat and source of living such as food and plants. Despite wild hog is known as omnivorous, most of its nutrition diet basically is plant-based [14]. The impact given by wild hog to plantation can either be positive or negative, unfortunately most of them are unpleasant effect. However, its role in seed dispersal and contribution in biodiversity and soil enrichment for plantation is something that are undeniable $[7,15]$.

\subsection{Wild Hog Management and Repellent Practices}

According to past studies, there were three popular methods used to reduce the nuisance of wild hog namely, through use of fences, hunting, food supplementary, and other repellent system [16, 1]. In some Euro countries, the use of electrical fences has become the most popular method of reducing the invasive activity of this species. Although the use of fencing system has been proven effective in reducing the invasive activity of this species, Schlageter in his review stated that the huge cost involved for regular inspection and maintenance has made this system to be not cost-effective [16]. Thus this method is considered to be ineffective in term of economic aspect. Meanwhile, Geisser and Reyer in their study had stated that, the activity of hunting is less efficient to reduce the invasive activity as this species has the ability to restore its population and has the ability to adapt with new environment [20]. Besides that, the activities of hunting is restricted by law and legislation. In Malaysia, special permit is required for hunting activity as issued under Firearms Act 1960 for Act 716 under Wildlife Conservation Act 2010. The practicality of the supplementary food has been debated for its effectiveness in overcoming the problem of this species as it allows them to survive and eventually contribute to their reproduction and growth [21]. Apart from that, the use of olfactory repellent has gained people's attention and is widely used to scare this species. In a study reviewed by Schlageter, the use of predator's urine can prevent pests from leaving the area [17]. However, it is quite challenging to collect the urine as most predators are dangerous and big scale repellent production using predator's urine is seems impossible and tedious. Morever, the use of artificial predator's urine will promote the use of chemical substances that have possibility to give harm to wildlife, human, plantation and against the animal act. Stephens in his study highlighted that, an ideal repellent should meet several criteria which are user-friendly; safe for both animals and human to give temporary protection from over-grazing, low-cost, easy to apply and time-saving [22]. The following Table 1 shows the summary for repellent practices that have been practiced by other countries, the implementation, and the source of citation. 
Table 1. Summary of the pest repellent practices adopted by other countries

\begin{tabular}{|c|c|c|c|}
\hline Practices & Application & Country & Citation source \\
\hline Human hair & $\begin{array}{l}\text { To control rhinoceros beetle (Oryctes } \\
\text { rhinoceros), to control wild boar (Sus } \\
\text { Scrofa), other ungulates, also as slow } \\
\text { release fertilizer. }\end{array}$ & $\begin{array}{l}\text { India (Assam) } \\
\text { India (Telangana) } \\
\text { USA, Mauritius }\end{array}$ & {$[23,24,25,26]$} \\
\hline $\begin{array}{l}\text { Mixture of dry fish } \\
\text { and fragmented } \\
\text { human hair }\end{array}$ & To control squirrel & India (Assam) & {$[25]$} \\
\hline $\begin{array}{l}\text { Mixture of fermented } \\
\text { urine with spices } \\
\text { (Curcuma domestica } \\
\text { Val, Tinospora crispa } \\
\text { (L.) Miers.hen jin t), } \\
\text { Capsicum frutescens } \\
\text { K., Allium sativum } \\
\text { Linn. }\end{array}$ & $\begin{array}{l}\text { Pest repellent, combining combination of } \\
\text { bitter component, spices to affect the } \\
\text { neural system of pests, heat effects, } \\
\text { strong taste, and urine to give a strong } \\
\text { smell which at the same time acts as a } \\
\text { fertilizer for soil. }\end{array}$ & Indonesia & {$[27]$} \\
\hline Human urine & $\begin{array}{l}\text { Biological pest control, human urine is a } \\
\text { cheap and easily available fertilizer. It is } \\
\text { rich with essential micro-nutrients for } \\
\text { crop and soil. }\end{array}$ & Uganda & {$[28]$} \\
\hline $\begin{array}{l}\text { Local pigs dung spray } \\
\text { solution }\end{array}$ & $\begin{array}{l}\text { Traditional pest controller for wild boar. } \\
\text { This prevents the movement of wild hog } \\
\text { by creating confusion in their territory. }\end{array}$ & India & {$[26]$} \\
\hline Egg solution spray & $\begin{array}{l}\text { The smelly sulfur smell of of egg is used } \\
\text { to control the browsing activity of wild } \\
\text { deer. It also has been used to deter wild } \\
\text { hog in India. Some commercialized } \\
\text { repellents also use it as deterrent. Among } \\
\text { the repellent are; Deer Away ® Big } \\
\text { Game Repellent, powder, IntAgra, Inc. } \\
\text { Minneapolis and Minn ( } 4.93 \% \text { putrescent } \\
\text { whole egg solids). }\end{array}$ & USA & [29] \\
\hline $\begin{array}{l}\text { Capsaicin and } \\
\text { capsaicinoid product }\end{array}$ & $\begin{array}{l}\text { The material is believed can to cause fear } \\
\text { to the pests through taste and irritant } \\
\text { effects. The pest repellent products that } \\
\text { use Capsaicin as an important material in } \\
\text { their products are Hot Sauce } ® \text {, Miller } \\
\text { Chemical and Fertilizer Corp, Hanover } \\
\text { PA ( } 0.53 \% \text { Capsaicin); Deer Away } ® \\
\text { Deer and Rabbit Repellent (DDR), } \\
\text { IntAgra, Inc., and Minneapolis, Minn } \\
\text { (0.625\% Capsaicin and related } \\
\text { compounds). }\end{array}$ & USA & [29] \\
\hline
\end{tabular}

\subsection{Human Scalp Hair (HSH) as Temporary Repellent and Other Practices}

For so many years, the conventional use of human scalp hair (HSH) has become the alternative to reduce the invasive activity of wild hog in agricultural sector, especially in palm oil industry. According to Murty, as these mammals using their snout to detect food and to survive, the use of HSH can potentially cause them severe respiratory irritation and fear to the swine. [18]. Kittawornrat in his study stated that their snout has enable them to survive since piglet phase [19]. Usually the adult female pig or sow can be found in groups, consisting of sow or her litter, while for the adult male, most of them companionless as shown in Figure 1.

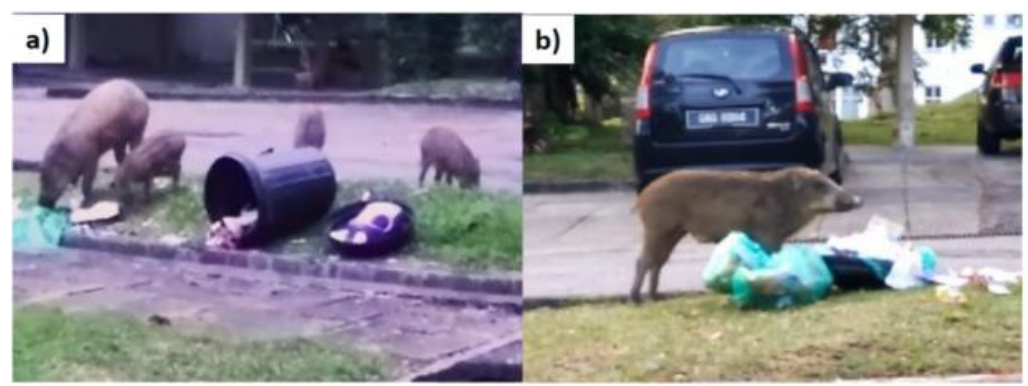

Figure 1. Footage of wild hog taken in 2016. This figure show (a) a female hog that move in group consisting of other sow and her litter and (b) the mature male hog that has found move in companionless. 
Hair waste is among waste material that accumulates the most water stream system which possibly can cause blockage in draining system. Although HSH is seen as waste material by many, its big potential in agricultural sector has proven otherwise and this shows how it is important in contributing for a hair salon waste management. According to Gupta, HSH has become an important element in agricultural over the years especially its usage as slow release fertilizer which could give essential nutrient for soil and plantation [24]. Some traditional practices of human hair showing that human hair is suitable to be used as repellent especially for ungulate such as wild deer, rabbit and wild hog as they use their sense of smell to track food and prey. The concept is, when the hair is sniffed by the ungulates, it will cause discomfort and difficulty in breathing and it will affect their tracking system. Despite the application of HSH which has been used for so many years, the inefficient and improper hair waste management and direct disposal of HSH possibly give negative impact to the environment. The direct use of HSH on land has led to odour problem and pathogen due to lack of treatment on hair before disposed. The inorganic material and oil that stick on the hair might cause unpleasant odour and breeding of pathogen if discharged on land. In agricultural, the use of HSH as repellent for wild hog has proven to be effective in reducing the nuisance by reduction from $40 \%$ to $50 \%$ [26]. Until now, the use of HSH on land does not emphasis on the method of processing prior its use in agricultural either as fertilizer, or as repellent. Table 2 shows HSH research efforts and up to now, the commercialization of HSH as repellent is still far behind.

Table 2. List of the countries conducting new research on HSH according to [24]

\begin{tabular}{|l|l|}
\hline \multicolumn{1}{|c|}{ New uses/areas of research } & \multicolumn{1}{c|}{ Countries } \\
\hline Liquid fertilizers & India, USA, Korea, and Bangladesh \\
\hline Concrete reinforcement & Canada, India \\
\hline Pollution control & $\begin{array}{l}\text { Canada, Singapore, India, Iran, Korea, } \\
\text { Egypt, and Jordan }\end{array}$ \\
\hline Molded furniture and objects & UK \\
\hline Engineering polymers & Singapore, China, Japan and India \\
\hline Follicle cell cultures/ tissue regeneration & Switzerland, UK, Korea and France \\
\hline Composite for superconducting systems & India, Grace, and The Netherlands \\
\hline Flexible microelectrodes & China \\
\hline
\end{tabular}

\subsection{METHODOLOGY}

\subsection{Hair Segregation, Multiple Hair Washing Process and Procedure}

According to Wilson [30], there is not standard washing procedure for hair. In order to reduce the impact of direct usage of hair onto land, washing procedure need to be developed. Meanwhile, Jenkin [31]. in his study state, despite there is no standard procedure for cleaning procedure of hair, various procedures and combination have been applied by past researchers such as using ethyl ether, acetone, soaps and detergents (ionic and non-ionic), EDTA ethylenediamine tetraacetate, dilute nitric acid and many more. In study conducted by Hammer [32], he used multiple washing by detergent, distilled water, ethanol, and boiling EDTA solution. However, the effectiveness for type of wash procedure is out of scope of this study as this study only focusing on the probability of hair waste application as temporary repellent.

The HSH collected from hair salon has undergone manually segregation process to separate the hair from visible pollutant such as shampoo bottle, plastic, hair clips and tissue. Hair that had been separated from the visible pollutant was placed in a clean polyethylene container and subsequently washed using mild detergent. Segregated HSH was washed using non-ionic detergent-acetone washing method $[33,34,35]$. Hair was washed using mild detergent at first to remove all visible dirt and oil. After that it was washed again with a 5\% dilution of non-ionic detergent, rinsed and hair is oven-dried overnight. Hair was then washed with 1:1 acetone and deionized water for 30 minutes and rinsed before hair is oven-dried at $100^{\circ} \mathrm{C}$ overnight. Acetone has been recommend in the past study to be use in hair wash process as it help in removing external contamination such as lead and grease [36]. Field test was conducted from 25th April 2017 until 29th April 2017 at a private orchard in Kampung Parit Mohamad, Bukit Bakri Muar. The process of hair segregation, hair washing is simplified as in Figure 2. 


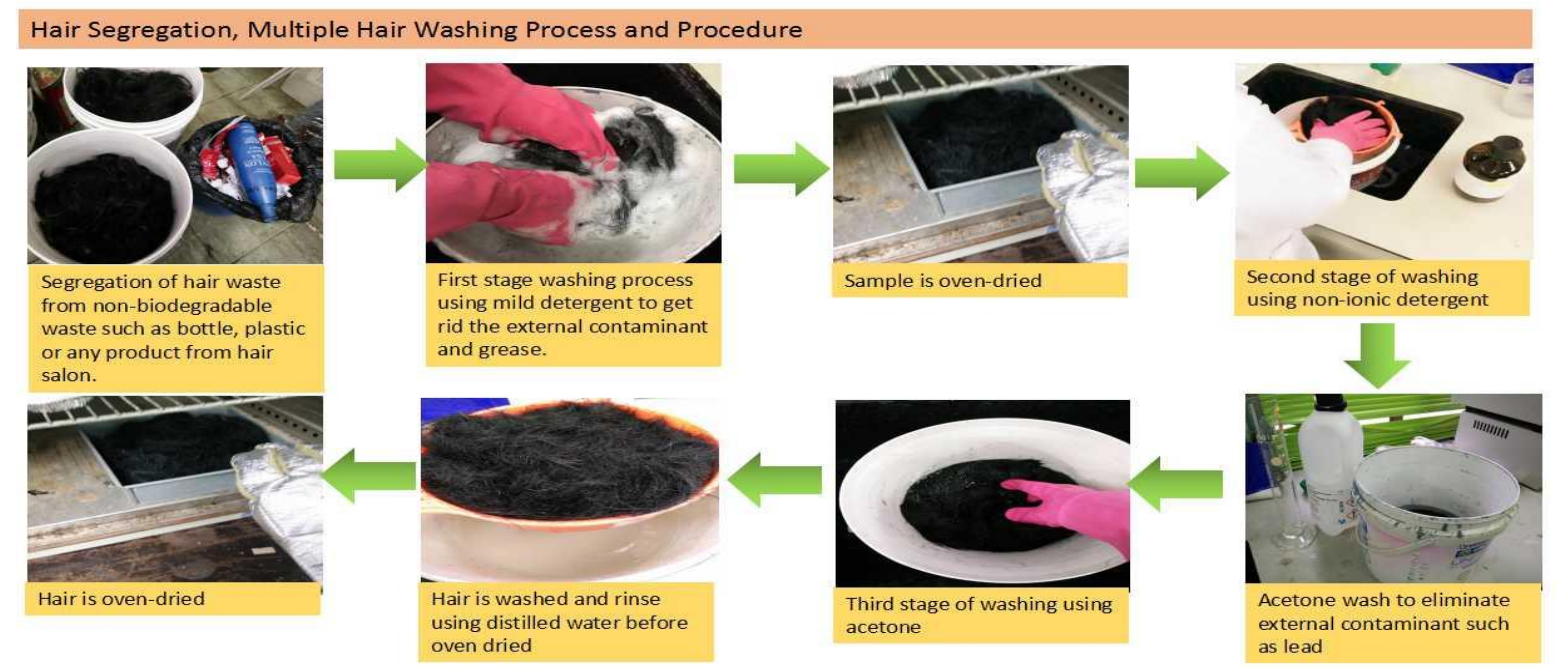

Figure 2. Collected hair from nearby hair salon was manually segregated and washed.

\subsection{Study Area}

This study has been conducted between 25th April 2017 and 29th April 2017 at an acre of private orchard planted with tapioca cassava tree, located in Kampung Parit Mohamad, Bukit Bakri, Muar. There were four (4) samples of food used as baits with each of them comprised of; (a) only whole kernel corn; (b) whole kernel corn with $20 \mathrm{~g}$ of HSH; (c) whole kernel corn with $40 \mathrm{~g}$ of $\mathrm{HSH}$; and (d) whole kernel corn with $60 \mathrm{~g}$ of $\mathrm{HSH}$. The amount of whole kernel corn used for sampling remained constant throughout the study. $5 \mathrm{~kg}$ of whole kernel corn was used for each sample every day of the experiment. The probability of wild hog visitation to the study area and their response to the use of hair is calculated from the remaining whole kernel corn throughout the study period.

\subsection{Bait Preparation}

Wild hog are known for their distinctive feature which is snout. This feature acts as their tracking system to find food, habitat, to identify their territory and prey. This system is developed since the piglet phase in order for them to survive [19]. Some farmers in the past used fish oil, vegetables, sweet and sour food as attractant to lure this species into the trap. In this study, feed corn was used to lure wild hog. The selection of whole kernel corn as bait was made since they are easy to obtain and often used in baiting [37] The corn was mixed with yeast, flavoured drink (strawberry and grape-flavoured) and water as shown in Figure 3. The sweetened smell of fermented corn with these ingredients is to draw attention of hog and to increase the probability of hog's visitation and presence at the study area. The mixture was mixed well and kept in clean polyethylene storage to let them fermented for 2 to 3 days before it can be used as bait.

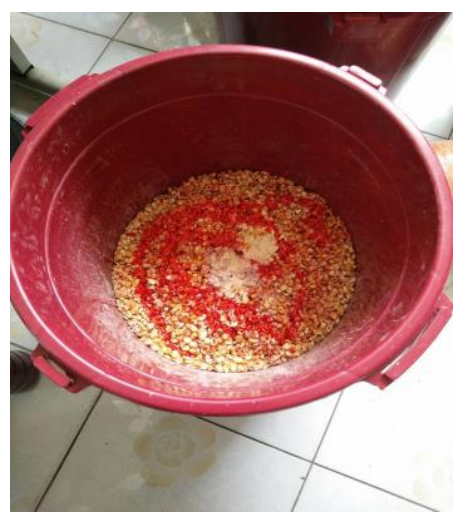

Figure 3. Whole kernel corn was mixed with flavoured drink, yeast and water. The mixture was mixed well before fermented for 2 to 3 days. 


\subsection{Repellency Test on the Field}

Commonly, the type of fear test used to measure the reaction of wild hog or species related to it is through open field test, novel object and the voluntary approach test [38]. In past study involving critical review of fear test for pig, open field test is not recommended as the only general fear test, as there is lack of connection with other test of fear [38]. Therefore, variation of measurement or instrument and repetition of variables is recommended to be used to capture and to interpret the behavioural tendencies of animal over the variable provided during the field test [38]. The time of this study and the study area was selected in April due to reports received on invasion of wild hog from local farmer at beginning of the month. Through observations and site visit, there is evidence that strengthens the presence of these animals into the study area through the effects of traces and tapioca plant that have been damaged by the animals as shown in Figure 4.

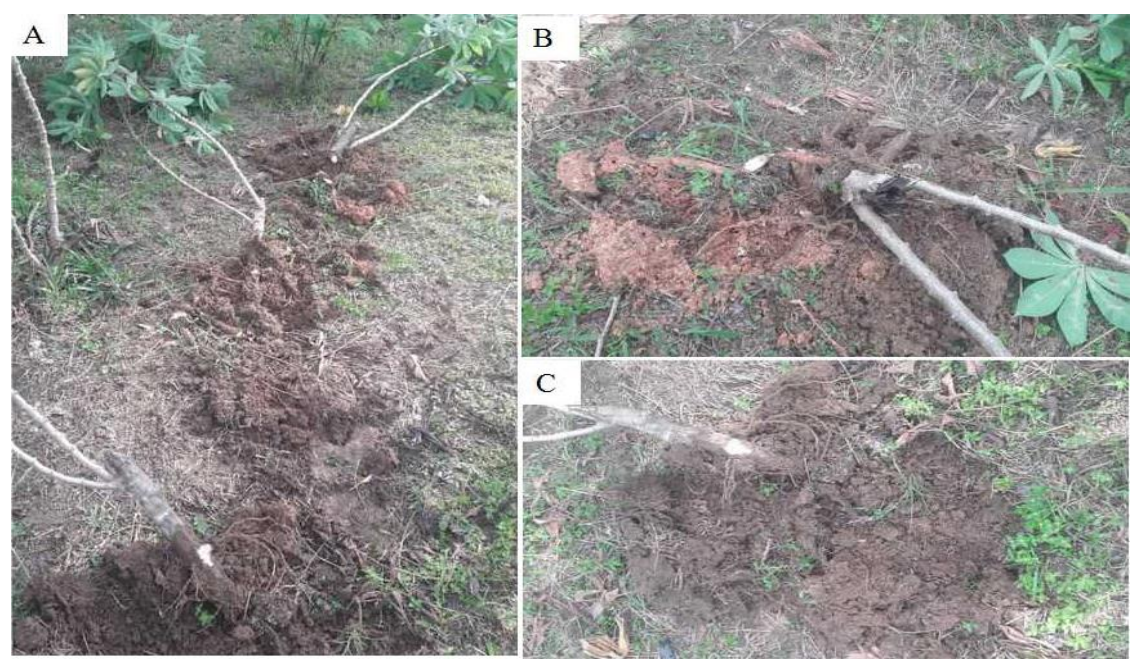

Figure 4. Photos taken during site visits on the study area. This figure shows (A) tapioca cassava tree that has been damaged during the wild hog invasion activities, (B) effect of rooting mechanism of wild hog on the immature tree and (C) traces of wild hog at the study area.

For this test, we used the combination of open field test and novel object. The open field test is through area that identified as impaired and for novel object is through usage of hair waste as temporary repellent and fermented whole kernel corn as bait to increase the probability of visitation. As this study is intended to investigate the probability usage of hair waste as temporary repellent, the voluntary approach test that involve presence of human is not suitable and it will interfere the process and findings of this study. In order to understand and to analyse wild hog behaviour towards introduction of human hair waste in target area, different amount of hair for each samples has been used in this study. Some studies in India has shown the usage of hair as traditional method to control invasive activity of wild hog [26]. However, there is no detail ratio or method mentioned. In this test, field trials were conducted using 4 samples namely as sample A, sample B, sample C and sample D and they were repeated for each day. $5 \mathrm{~kg}$ of fermented whole kernel corn were used for four (4) samples per day; (1) $5 \mathrm{~kg}$ fermented whole kernel corn (sample A); (2) $5 \mathrm{~kg}$ fermented whole kernel corn mixed with $20 \mathrm{~g} \mathrm{HSH}$ (sample B); (3) 5kg fermented whole kernel corn mixed with 40g HSH (sample C); and (4) $5 \mathrm{~kg}$ fermented whole kernel corn mixed with 60g HSH (sample D). The field test observed the effectiveness of the repellent through measuring the weight before and after feeding baits were used. The process is simplified as in Figure 5. Figure 6 shows the presence of wild hog that has entered to the study area on the day-3 of field trial. 


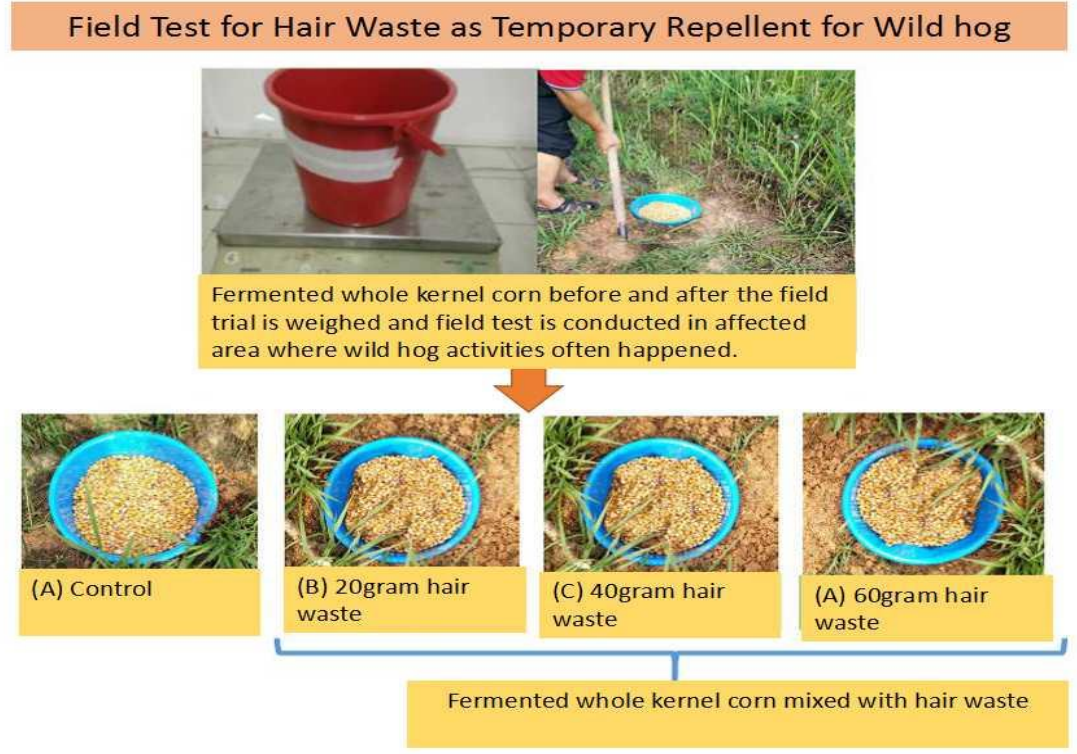

Figure 5. The whole kernel corn mixtures were weighed before and after the repellency test. The 5 day results were observed and recorded.

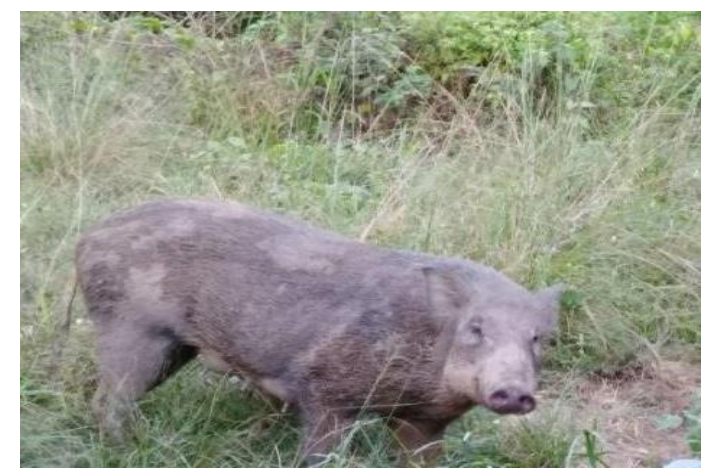

Figure 6. An image of wild hog taken from the study area during the observation.

\subsection{RESULTS AND DISCUSSION}

The overall result for weight of sample along the 5 days field trial is depicted as in Table 3 . The total weight of whole kernel corn readings (in percentage) show a slight change in day-1 and day-2 as shown in Figure 7 and Figure 8 . For day-1, small change in weight of whole kernel corn can be seen with sample A (control) show about $10.6 \%$ of whole corn was eaten, while for day-2, $11 \%$ of the total whole corn is consumed during the field test. Samples B, C, and D, that has mixed with hair waste did not show any significant change with B $(2 \%), \mathrm{C}(0.2 \%)$, and D $(2 \%)$ for reading of eaten sample on day-1, while for day2 is $\mathrm{B}(4 \%), \mathrm{C}(0.2 \%)$ and $\mathrm{D}(1.4 \%)$. This readings interpret the possibility of no wild hog enter the study area during that days. However, the slight change in readings for samples during day-1 and day-2 might contributed by other small pests such as small.

Table 3. The finding for weight of samples eaten during the field trial

\begin{tabular}{lcccc}
\hline \multirow{2}{*}{ Day } & \multicolumn{4}{c}{ Sample (in kg) } \\
\cline { 2 - 5 } & A & B & C & D \\
\hline Day-1 & 0.53 & 0.10 & 0.01 & 0.10 \\
Day-2 & 0.55 & 0.20 & 0.01 & 0.07 \\
Day-3 & 2.95 & 0.04 & 0.00 & 0.00 \\
Day-4 & 3.06 & 0.00 & 0.00 & 0.00 \\
Day-5 & 2.00 & 0.00 & 0.00 & 0.00 \\
\hline
\end{tabular}




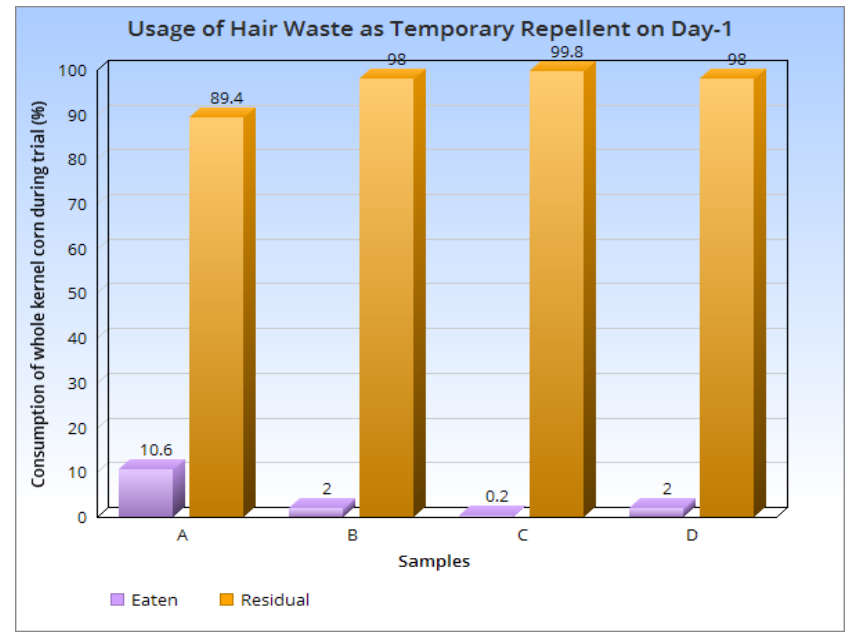

Figure 7. Field test result on probability usage of hair as temporary repellent on day-1

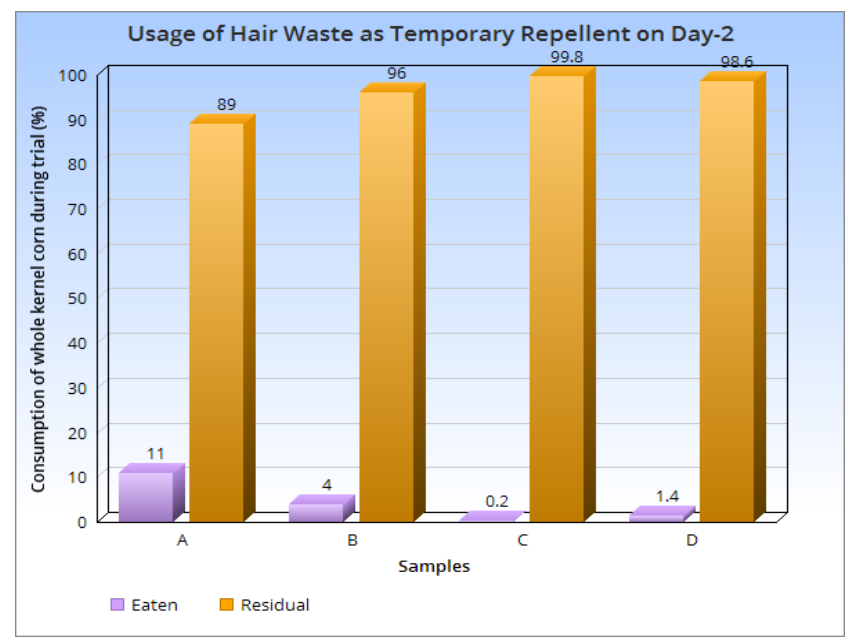

Figure 8. Field test result on probability usage of hair as temporary repellent on day-2

Meanwhile, the results for day-3 and day-4 show the possibility presence of wild hog through a major change in reading of total whole kernel corn especially for sample A (control) as shown in Figure 9 and Figure 10. For day-3, 59\% of whole kernel corn was eaten, while $61.2 \%$ of whole kernel corn was eaten on day-4 for sample A. However, readings for samples eaten during the field trial for sample B, C, and D for both days did not show any significant change, only minor change can be seen for percentage whole corn eaten from sample B on day-3 which is about $0.8 \%$ that might be contributed by small pest like bird. Wild hog rely entirely on their olfactory sense as they have weak mechanism for both hearing and sighting [26]. In order to find food and location, wild hog used their special feature which is snout to sniff from one place to another. The use of hair can cause irritation to their respiratory tract as they inhale the hair during sniffing. This can create fear or sense of aware. This interpretation may be appropriate based on observation on sample B, C, and D that are not eaten and shunned by hogs as they mixed with hair during the test. 


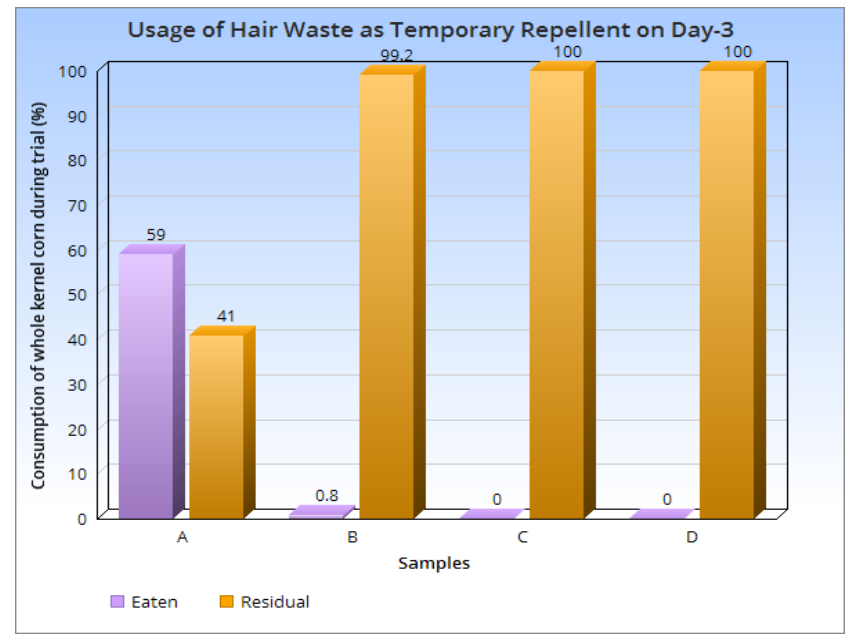

Figure 9. Field test result on probability usage of hair as temporary repellent on day-3

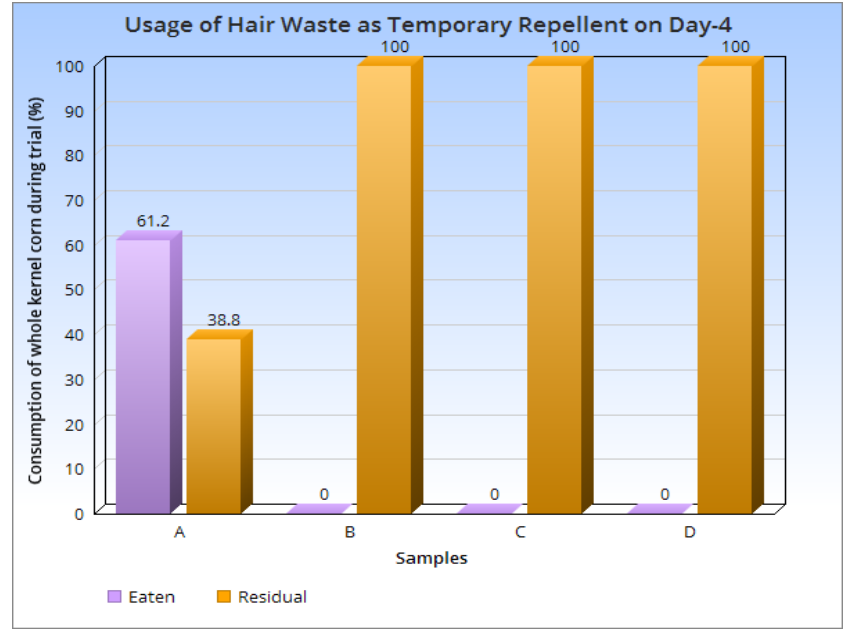

Figure 10. Field test result on probability usage of hair as temporary repellent on day-4

The day- 5 reading indicates the sensitiveness of wild hog towards the use of hair through the reduction of food consumed in sample A as shown in Figure 11. For sample A (control), the reading for whole kernel corn consumed on day-5 showed a decrease with $40 \%$ of whole corn eaten compared to $61 \%$ of total whole corn consumed on the day- 4 . Meanwhile, samples B, $\mathrm{C}$ and D remain unchanged. There are various possible opinions related to change in reading and behaviour of wild hog, namely; the use of hair has caused fear and respiratory irritation to the wild hog and the possibility of they move to elsewhere for source of food. Past review from study conducted by Gray stated that fear by an event is developed through general characteristic such as movement, intensity, duration, bewilderment, consternation, unexpected event and closeness [39]. The sudden introduction of hair waste in the study area might has create bewilderment and fear along with usage of bait which is fermented corn to increase the probability of wild hog visitation. 


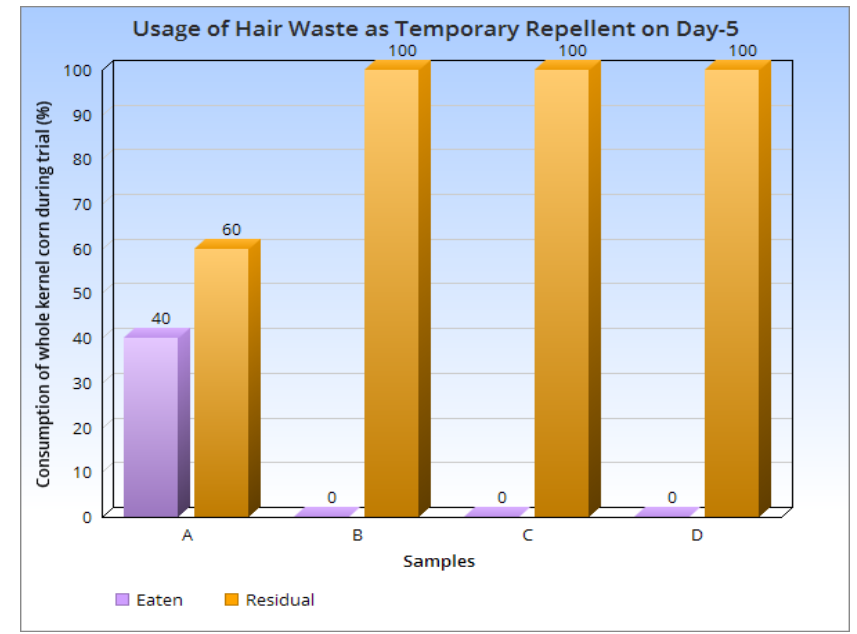

Figure 11. Field test result on probability usage of hair as temporary repellent on day-5

\subsection{CONCLUSION}

Through this pilot test, it indicates the probability and potential usage of hair waste as temporary repellent from problem of wild hog invasion into agricultural land and to reduce impact of invasion such as damage of crops. In developing animal repellent, several requirement need to fulfill and to be taken into account. An ideal repellent need to meet these several criteria namely; user-friendly; cost-effective; easy to use; saves time; provide temporary protection from over-grazing; and safe for both animals and human [22]. The use of variety repellent and pesticide that can be found in the market maybe effective in protecting crops, however the use of chemical substances that can potentially give a long-term impacts to environmental, soil, human and plantation need to be considered. The long-term usage of some method of controlling the invasion of wild hog might harm the wild hog and might led to deterioration of this species that also well-known as natural heritage and protected by legislation and policies. This study is not only to share the possibility usage of hair waste in agricultural, but at the same time to promote and expose the potential of hair waste and its value in agricultural. This study will significantly contribute to waste management and safe disposal. Further studies in a controlled environment and under supervision from Department of Wildlife and National Park (PERHILITAN) are currently being carried out in order to build characteristic and to obtain optimum value of hair waste usage as repellent along with other eco-friendly material for land usage.

\section{Acknowledgements}

The authors would like to express sincere gratitude to farmers of Kampung Parit Mohamad for letting us to conduct the field study. Appreciation and thanks also to the technical assistant and technician staff from Universiti Teknologi Malaysia (UTM) Environmental Engineering Laboratory who were willing to help and provide equipment for the purpose of this study. This study complies with the animal act 1953. No animal was harmed, abused or involved in cruelty as this study used only natural repellent which was not only safe for humans and plantations, but also for wild hog.

\section{References}

[1] Geisser, H. 1998. The wild boar (Sus scrofa) in the Thurgau (northeastern Switzerland): Population Status,Damages And The Influence Of Supplementary Feeding On Damage Frequency. Gibier Fane Sauvage-Game and Wildlife. 15: 547-554.

[2] Brauer, A., Lange, E. and Kaden, V. 2006. Oral Immunisation Of Wild Boar Against Classical Swine Fever: Uptake Studies Of New Baits And Investigations On The Stability Of Lyophilised C-Strain Vaccine. European Journal of Wildlife Research, 52(4): 271-276.

[3] Herrero, J., Garcı'a-Serrano, A., Couto, S., Ortun o, V. M., and Garcı'a-Gonza' lez, R.. 2006. Diet of Wild Boar Sus Scrofa L. And Crop Damage In An Intensive Agroecosystem. European Journal of Wildlife Research. 52:245-250.

[4] Bratton, S. P. 1977. Wild Hogs In The United States-Origin And Nomenclature. Research And Management Of Wild Hog Populations. The Belle W. Baruch Forest Science Institute of Clemson University, Georgetown. 1-4.

[5] Barrios-Garcia, M. N. and Ballari, S. A. 2012. Impact of wild boar (Sus scrofa) in its introduced and native range: A review. Biological Invasions. 14(11): 2283-2300.

[6] Schupp, E. W. 1993. Quantity, Quality, And The Effectiveness Of Seed Dispersal By Animals. Vegetatio. 107/108: 15-29. 
[7] Welander, J. 1995. Are Wild Boars A Future Threat To The Swedish Flora?. Ibex. Journal of Mountain Ecology. 4: 165-167.

[8] Habib, A., Nazir, I., Fazili, M. F., and Bhat, B. A. 2015. Human-Wildlife Conflict-Causes, Consequences And Mitigation Measures With Special Reference to Kashmir. The Journal of Zoology Studies. 2(1): 26-30.

[9] Massei, G., and Genov, P. V. 2004. The Environmental Impact Of Wild Boar. Galemys. 16: 135-145.

[10] Diong, C.H. 1973. Studies of the Malayan Wild Pig in Perak and Johor. Malay. Nat. Journal. 26: 120-151.

[11] McLeod, R. and Norris, A. 2003. Counting the Cost: Impact of Invasive Animals in Australia 2004. Canberra, Australia, Cooperative Research Centre for Pest Animal Control. 1-82.

[12] Lowe, S., Browne, M., Boudjelas, S. and De Poorter, M. 2000. 100 of the World' S Worst Invasive Alien Species: A Selection from the Global Invasive Species Database. Auckland, New Zealand, The Invasive Species Specialist Group (ISSG), 1-11.

[13] Lamarque, F., Anderson, J., Fergusson, R., Lagrange, M., Osei-Owusu, Y. and Bakker, L. 2009. Human-Wildlife Conflict In Africa: Causes, Consequences And Management Strategies. FAO Forestry Paper. Rome, Italy, Food and Agriculture Organization of the United Nations (FAO).

[14] Genov, P. 1981. Significance of Natural Biocenoses And Agrocenoses As The Source Of Food For Wild Boar (Sus scrofa L.). Ekologia Polska. 29(1): 117-136.

[15] Schupp, E. W. 1993. Quantity, Quality And The Effectiveness Of Seed Dispersal By Animals. Vegetatio. 107/108: 15-29.

[16] Schlageter, A., and Haag-Wackernagel, D. 2012. A Gustatory Repellent For Protection Of Agricultural Land From Wild Boar Damage: An Investigation On Effectiveness. Journal of Agricultural Science. 4(5): 61-68.

[17] Schlageter, A. 2015. Preventing Wild Boar" Sus Scrofa" Damage-Considerations For Wild Boar Management In Highly Fragmented Agroecosystems. Doctoral dissertation. University of Basel.

[18] Murty, M. L. K. 2001. Cultural Ecology of the Eastern Ghats (South India) from Pre-historic Times to the Ethnographic Present. Peoples and Environment in India. New Delhi. Discovery Publishing House. 51-78.

[19] Kittawornrat, A., and Zimmerman, J. J. 2011. Toward a Better Understanding Of Pig Behavior And Pig Welfare. Animal Health Research Reviews. 12(01): 25-32.

[20] Geisser, H., and Reyer, H. U. 2004. Efficacy of Hunting, Feeding, And Fencing To Reduce Crop Damage By Wild Boars. Journal of Wildlife Management. 68(4): 939-946.

[21] Cellina, S. 2008. Effects of Supplemental Feeding On The Body Condition And Reproductive State Of Wild Boar Sus scrofa in Luxembourg. Dissertation, University of Sussex, Brighton, UK.

[22] Stephens, O. L., Mengak, M. T., Osborn, D., and Miller, K. V. 2005. Using Milorganite® to Temporarily Repel White-Tailed Deer From Food Plots. Warnell School of Forestry and Natural Resources, University of Georgia, Wildlife Management Publication Series. WMS-05-02. 1-7

[23] Scott, J. D., and Townsend, T. W. 1985. Methods Used By Selected Ohio Growers To Control Damage By Deer. Wildlife Society Bulletin (19732006). 13(3): 234-240

[24] Gupta, A. 2014. Human Hair "Waste" and Its Utilization: Gaps and Possibilities. Journal of Waste Management. 2014: 1-17.

[25] Deka, M. K., Bhuyan, M., and Hazarika, L. K. 2006. Traditional Pest Management Practices Of Assam. Indian Journal of Tradisional Knowledge. 5(1): 75-78.

[26] Rao, V. V., Naresh, B., Reddy, V. R., Sudhakar, C., Venkateswarlu, P., and Rao, D. R. 2015. Traditional Management Methods Used To Minimize Wild Boar (Sus Scrofa) Damage In Different Agricultural Crops at Telangana state, India. International Journal of Multidisciplinary Research and Development. 2(2): 3 